\title{
Logo Counseling for Low Spiritual Self-Esteem Among College Students
}

\author{
Jacob Daan Engel ${ }^{1}$, Lobby Loekmono ${ }^{2}$, \\ ${ }^{1}$ Faculty of Theology, Satya Wacana Christian University, Indonesia \\ ${ }^{2}$ Faculty of Teacher Training and Education, Satya Wacana Chrsitian University, indonesia
}

\begin{tabular}{l} 
Article Info \\
\hline Article history: \\
Received Jun 9, 2018 \\
Revised Aug 8, 2018 \\
Accepted Aug 11, 2018 \\
\hline
\end{tabular}

Keyword:

College students Logo counseling Logo counseling model Low spiritual self-esteem

\begin{abstract}
The purpose of this research was to examine logo counseling model in improving low spiritual self-esteem problem for college students. This research used descriptive method and quasi-experiment method with a non-equivalent pre-test-post-test control group design. The results then analyzed from the statistical significance and the practical significance. The result showed that logo counseling model could improve low spiritual self-esteem among college students, indicated by statistical significance of $t_{\text {count (43.851) }}>t_{\text {table (2.144) }}$ and $N$ gain of the experimental group $(0.75)>N$-gain of the control group $(0.15)$ and practical significance of positive attitude, behavior and value changes. Recommendation also given for related agencies to implement logo counseling model in training program and for further research by related experts in the field.
\end{abstract}

Copyright (C) 2018 Institute of Advanced Engineering and Science. All rights reserved.

\section{Corresponding Author:}

Jacob Daan Engel, Faculty of Theology, Satya Wacana Christian University, 52-60 Diponegoro Street, Sidorejo, Salatiga 50711, Indonesia. Email: jacop.daan@staff.uksw.edu

\section{INTRODUCTION}

Over the past decades, self-esteem has emerged as an important tool for understanding human behavior and treating negative thoughts, self-doubt, and self-hatred [1]. Basically, self-esteem is how confident a person to think and cope with the challenges of life. Self-esteem has become a very important attribute for identifying the adaptiveness of a person to the increasingly complex and challenging world [2]. People may build healthy or low self-esteem. Healthy self-esteem is when people can assess and know themselves accurately and still accept and value themselves completely [1]. At the same time, low selfesteem people judge their capability and values or virtues skeptically. People who have low self-esteem will overemphasize their weaknesses and deficits and underestimate their strengths and assets [3].

Many college students facing a highly stressful process when transitioning into college life [4]. Not to mention violence, alcohol and drugs abuse, sexual harassment and social pressure happening made students more vulnerable to low self-esteem problem [5]. Low self-esteem has been commonly associated with clinical disorders, such as depression, eating disorders, substance abuse, and psychosis [3,6]. In addition, some studies indicate that low self-esteem foresee antisocial behavior, interpersonal violence, depression, and anxiety [7][8]. Therefore, it is important to address and acknowledge what is low self-esteem and, more importantly, how to identify and treat low self-esteem.

Numerous studies had been conducted to treat low self-esteem as a cognitive problem [3,6,9-11]. These treatments considered as cognitive behavior therapy (CBT) program and based on Fennel's cognitive conceptualization of low self-esteem [12]. These low self-esteem treatments mentioned only focused on how 
to modify external stimuli and behaviors, but not addressing how the clients think and feel at the core of their selves. CBT addresses cause-and-effect relationship with cognition without addressing client's free will. CBT believes that human beings do not have free will and are influenced just by the cognitive processes appealed to external stimuli [13]. Besides the problem in its foundation, the effectiveness of CBT for low self-esteem has yet to be systematically evaluated [14] and it seems that CBT's effectiveness has been declining according to a recent meta-analysis research [15].

Authors suspected that there was some mismatch concept in the CBT-based low self-esteem treatments. Some researchers had argued that low self-esteem was a deeper problem related to spirituality[4,16]. The underlying core of humanity, as Holloway [17] said, is meaning and purpose which integrated in spirituality. Spirituality is frequently highlighted with attributes of love, joy, compassion, caring, awe, wonder and mystery, beauty and creativity [17]. Then, in a study of 105 social work graduate students, it was found that spiritual well-being was related to higher self-esteem [16]. Pedersen [18] found that among 134 undergraduates, those with a stronger or central spiritual identity had higher self-esteem. These studies are confirming the authors' supposition that low self-esteem is a problem at the spiritual level. Thus, it is a necessary attempt to treat low self-esteem with spiritual and humanistic approaches. One of the well-known spiritual and humanistic-based approach is logotherapy developed by Victor Frank1 [19,20].

In this article, authors examined low self-esteem problem from Victor Frankl's logotherapy perspective as an approach to understanding human from the spiritual aspect that reflects the need to reach the meaning of life. The goal of logotherapy is to express a will to be meaningful in achieving the meaning of life. Although logotherapy can be used in wide range of issues of meaning of life [21,22], there is almost no research in applying logotherapy for low self-esteem. The authors apply literature study approach to analyze the core problem of low self-esteem and developed a new model based on logotherapy which yields logo counseling. Logo counseling provides counselors with the meaning of life counseling for treating low selfesteem. Then, we examine the effectiveness of logo counseling to treat low spiritual self-esteem among college students with indicators of statistical significance and practical significance.

\subsection{Low Spiritual Self-Esteem}

Lim analyzed factors causing low spiritual self-esteem more broadly than Branden's approach [23]. The causal factors of low spiritual self-esteem are negative life experience, negative core beliefs, negative self-assumptions, expectation bias, negative self-evaluation, and self-distrust [1][23], explained as [24,25]: (1) Negative life experience of the past is the inability to address problems and events that have occurred once or many times. It is harmful and it brings a bad precedent to one's thinking ability. (2) Negative core belief is the inability of an individual to see himself as a result of past negative experiences; (3) In line with negative core beliefs, an individual often tries to develop negative assumptions, which he thinks, will help him protect himself from bad effects; (4) Expectation bias is the inability to face negative feelings that overestimate the possibilities of bad things to happen; (5) Negative self-evaluation is the inability to deal with the feeling of self-blame and self-critical such as "I'm useless", "stupid", "I never learn," and "everything is destroyed"; (6) Self-distrust is the inability to understand the empty and meaningless life which happens for a long time.

These six causative factors will make impacts on the six pillars of self-esteem [26], i.e. selfawareness, self-acceptance, self-determination, life purpose, self-responsibility, and self-integrity. The impacts of those causal factors are negative self-awareness, negative self-acceptance, negative selfdetermination, negative life purpose, negative self-responsibility and negative self-integrity[27]. These low spiritual self-esteem problems are visualized in Figure 1.

\subsection{Logotherapy}

Logotherapy generally can be described as psychology that recognizes spiritual dimension in human besides physical and psychiatric aspect [28]. The main philosophical foundations of logotherapy are freedom of will, will of meaning, and meaning of life with each source of meaning [28]. Logotherapy provided counselors with three techniques and each technique accompanied by an approach. They are paradoxical intention with the approach of self-detachment, de-reflection with self-transcendence approach and Socratic dialogue with the approach of self-awareness [28]. The holistic view of logotherapy can be seen in Figure 2. 


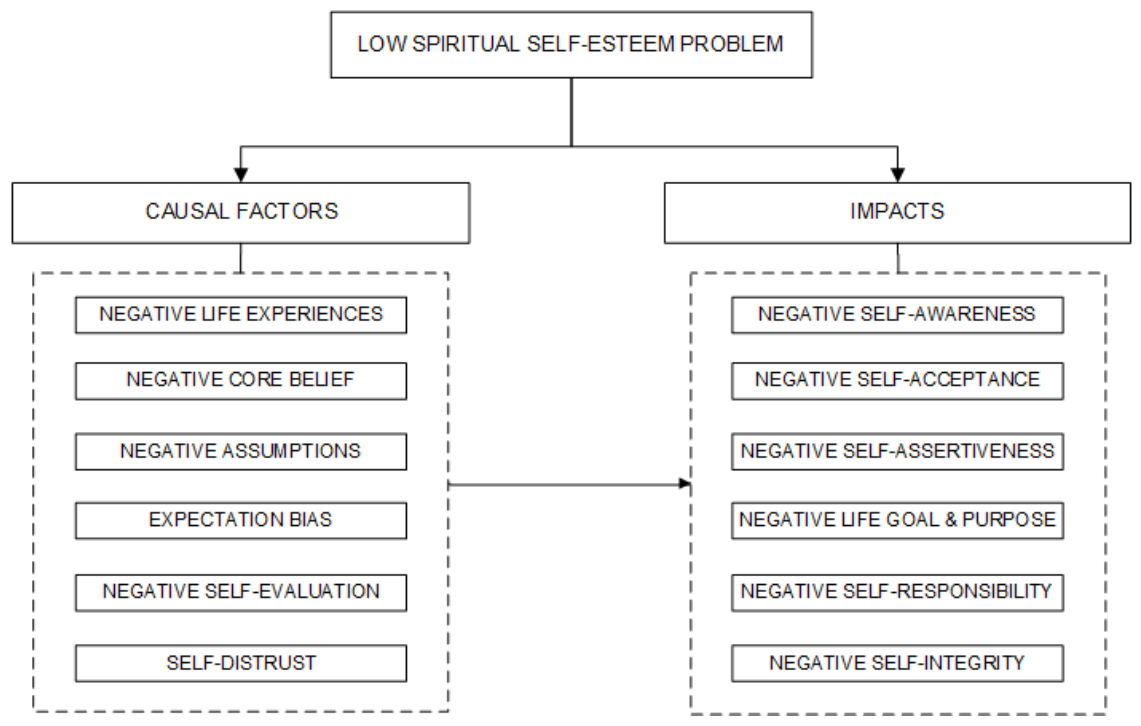

Figure 1. Description of low spiritual self-esteem problem illustrating the causal factors and the impacts of it

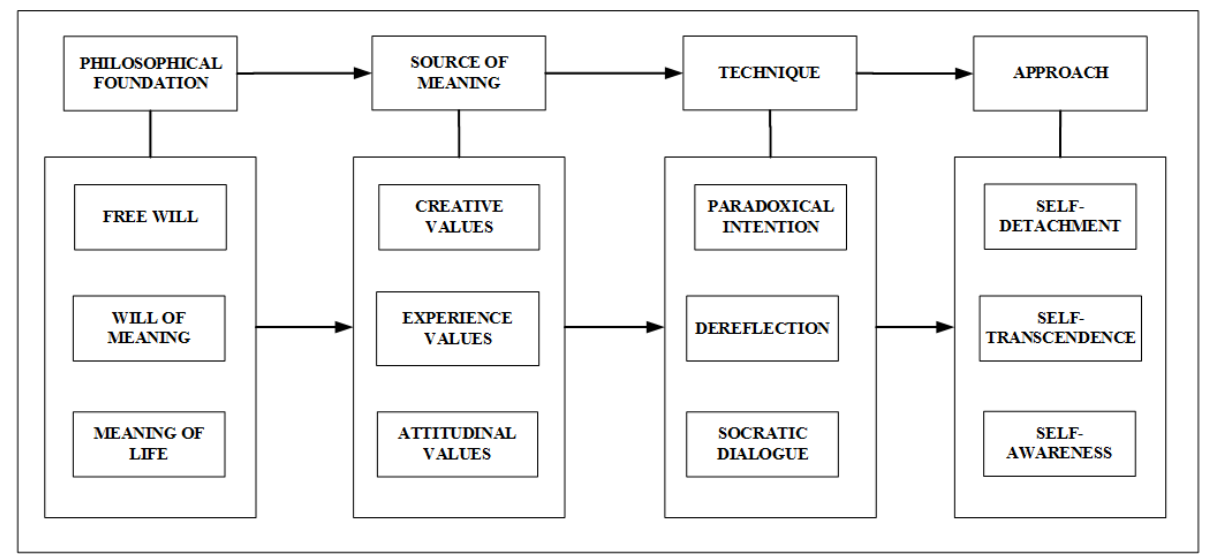

Figure 2. Frankl's logotherapy model only provides three techniques and approaches

\subsection{Logo Counseling}

Seen from the perspective of logotherapy, there is need gaps for low self-esteem treatments. There are six problems arise from the discussion of causative factors and impacts of low self-esteem, while logotherapy in the perspective of Frankl only provides three techniques and approaches. Authors developed logo counseling hypothetic model for treating low self-esteem. Purposes of logo counseling is to overcome the causative factors of low self-esteem and the achievement targets of logo counseling is to strengthen six pillars of self-esteem. Logo counseling supplement one additional session focusing on meaning orientation. The ultimate goal and target of the logo counseling model is to gain a healthy self-esteem as well as the discovery of meaning and purpose in life. Logo counseling model is shown in Figure 3.

Logo counseling model consisted of seven sessions, with each session using a different technique. Session 1 used self-exploration technique for client to explore her relationships, mindsets, emotions, behaviors, and experiences. Session 2 used self-acceptance technique to bring the client to accept his or her self, visual physique, characters, hurt experience, skills, and talent. Session 3 used a self-detachment technique to help the client making distance with her problems symptoms and fears. Session 4 used selftranscendence technique for the client to see herself beyond and focus towards values and meanings. Session 5 used behavior modification technique to help client identifying herself not based on a situation, but she 
could control her attitude toward the same situation. Session 6 used a self-integrity technique to listen and ask provocative questions. Finally, session 7 used meaning realization technique to help client finding meaning.

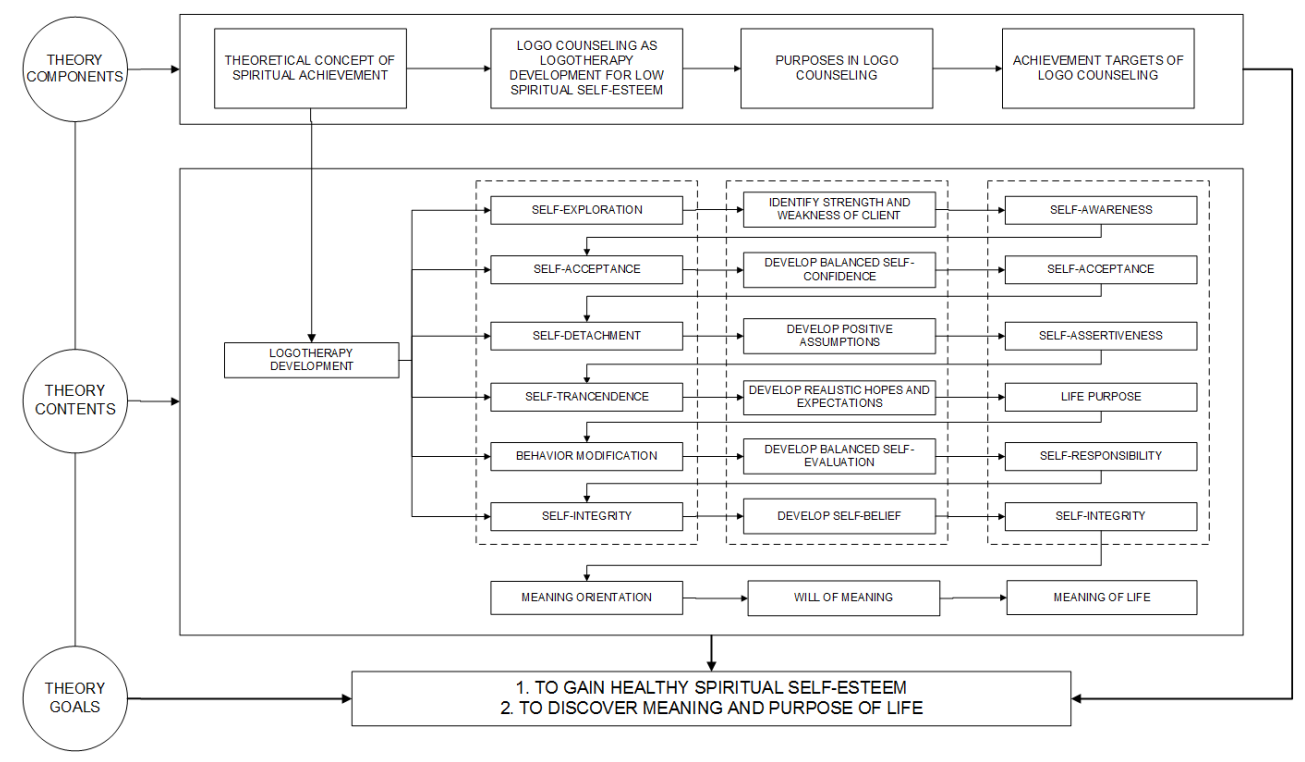

Figure 3. Logo counseling model as a logotherapy development for treating low spiritual self-esteem

\section{RESEARCH METHOD}

We chose descriptive method [29] and quasi-experiment method with a non-equivalent pre-testpost-test control group design [30] to describe and analyze facts and characteristics accurately. The criteria of the achievement results will be described as statistical significance and practical significance [29,30]. We chose 30 Satya Wacana Christian University students as participants, 15 individuals were in an experimental group and 15 individuals were in a control group. The authors engaged in collaboration through a partnership with three guidance and counseling experts as well as two counseling practitioners in model validation test. The research will conduct interviews, observations, questionnaires, and focus group discussions (FGD) to gather qualitative and quantitative data. We use interviews to obtain a general overview of the problems. Questionnaires were distributed using a semantic differential scale, bipolar characteristics (two opposing pole ends, negative-positive) with a range of $0-10$. An observation was an examination process towards a research subject and conducted in a structured manner [31]. The goal of FGD was to discuss and carry on a dialog together, to produce a piece of information directly from various views [31]. Questionnaires were deployed to gather statistical significance data. Interviews, observations, and FGD were deployed to gather practical significance data.

Data gathered in this research were qualitative and quantitative data. Qualitative data were used in non-statistical analysis to test the feasibility of the logo counseling model. Quantitative data were used in statistical analysis to test the instrument scale in development problems and to measure the impact of the model. The techniques to analyze the instrument scale and the usefulness of the model were validity and reliability tests, normality and homogeneity tests, average differential tests, and emphasis of average differential tests.

\section{RESULTS AND DISCUSSION}

From the questionnaires distributed to the participants to measure low spiritual self-esteem in 30 student participants with 51 validated question items. we obtained following results.

Normality test showed that all data were normally distributed for experiment and control group, indicated by all the significant values being bigger than 0.05 , whether for the Kolmogorov-Smirnov test or the Shapiro-Wilk test, so that $H o$ was accepted and $H_{l}$ was rejected, which means the distribution data was normal. Homogeneity test (see Appendix) showed that all data were homogenous for experiment and control group, indicated by a significant value (Levene Sig) being bigger than 0.05 , so that $H o$ was accepted and $H_{l}$ was rejected, which means the data has the same variance or homogenous. 
A further statistical test was conducted by looking at the average pre-test and post-test results and comparing the two averages using a t-test. Average of pretest and posttest results will become the indication whether the approach of logo counseling model could improve low spiritual self-esteem problem. The results are shown in Table 1.

Table 1. Average Pre-test and Post-test Results for Experiment and Control Group

\begin{tabular}{|c|c|c|c|c|c|c|}
\hline No & $\begin{array}{l}\text { Dimensions and } \\
\text { Development }\end{array}$ & Source & Data & $\begin{array}{l}\text { Average } \\
\text { (Mean) }\end{array}$ & $\begin{array}{c}\text { Standard } \\
\text { Deviation }\end{array}$ & $\mathrm{N}$ - Gain \\
\hline \multirow{4}{*}{1} & \multirow{4}{*}{ Self-Awareness } & Experiment & Pre-test & 34.15 & 4.51 & 0.43 \\
\hline & & & Post-test & 83.70 & 2.48 & \\
\hline & & Control & Pre-test & 42.67 & 4.85 & 0.03 \\
\hline & & & Post-test & 46.11 & 5.97 & \\
\hline \multirow{4}{*}{2} & \multirow{4}{*}{ Self-Acceptance } & Experiment & Pre-test & 32.07 & 3.66 & 0.44 \\
\hline & & & Post-test & 84.37 & 1.42 & \\
\hline & & Control & Pre-test & 43.03 & 6.36 & 0.06 \\
\hline & & & Post-test & 49.93 & 4.29 & \\
\hline \multirow{4}{*}{3} & \multirow{4}{*}{ Self-Assertiveness } & Experiment & Pre-test & 30.67 & 4.95 & 0.45 \\
\hline & & & Post-test & 85.00 & 2.90 & \\
\hline & & Control & Pre-test & 45.17 & 6.01 & -2.38 \\
\hline & & & Post-test & 44.92 & 4.26 & \\
\hline \multirow{3}{*}{4} & \multirow{4}{*}{ Life Purpose } & Experiment & Pre-test & 32.38 & 3.12 & 0.43 \\
\hline & & & Post-test & 82.76 & 1.82 & \\
\hline & & Control & Pre-test & 42.28 & 6.19 & 0.02 \\
\hline & & & Post-test & 44.00 & 6.42 & \\
\hline \multirow{4}{*}{5} & \multirow{4}{*}{ Self-Responsibility } & Experiment & Pre-test & 32.08 & 4.62 & 0.42 \\
\hline & & & Post-test & 82.17 & 1.62 & \\
\hline & & Control & Pre-test & 45.62 & 3.51 & 0.03 \\
\hline & & & Post-test & 48.67 & 6.58 & \\
\hline \multirow{3}{*}{6} & \multirow{4}{*}{ Self-Integrity } & Experiment & Pre-test & 34.26 & 4.04 & 0.42 \\
\hline & & & Post-test & 82.33 & 1.45 & \\
\hline & & Control & Pre-test & 43.23 & 2.39 & 0.07 \\
\hline \multirow{5}{*}{7} & & & Post-test & 50.20 & 3.54 & \\
\hline & \multirow{4}{*}{ Meaning of Life } & Experiment & Pre-test & 166.07 & 23.59 & 0.75 \\
\hline & & & Post-test & 452.27 & 14.89 & \\
\hline & & Control & Pre-test & 205.93 & 18.60 & 0.15 \\
\hline & & & Post-test & 251.80 & 12.71 & \\
\hline
\end{tabular}

Table 1 showed a significant increase in the average pre-test and post-test results of the experiment group related to the problem of low spiritual self-esteem, while there wasn't any significant increase in the average pre-test and post-test results of the control group. This result indicated that the technique and approach used in logo counseling model could improve the low spiritual self-esteem problem in college students.

We used differential test of averages to compare whether there was a difference between control group and experiment group. The hypotheses are $\mathrm{H}_{0}$ : There is no difference of low spiritual self-esteem development dimension between students following the logo counseling intervention with students not following the program, and $\mathrm{H}_{1}$ : There is a difference of low spiritual self-esteem development dimension between students following the logo counseling intervention with students not following the program. Testing criteria is if $\alpha<$ (sig value) then $\mathrm{H}_{0}$ will be accepted and if $\alpha>$ (sig value) then $\mathrm{H}_{1}$ will be accepted. The results are shown in Table 2.

Table 2. Recapitulation of Differential Test Results of Pre-test and Post-test Average of Experiment and

\begin{tabular}{|c|c|c|c|c|c|c|c|}
\hline \multicolumn{8}{|c|}{ Control Group } \\
\hline No & $\begin{array}{c}\text { Dimensions and } \\
\text { Development }\end{array}$ & Group & Mean & $\mathrm{df}$ & $t$ count & $\mathrm{t}$ table & $\begin{array}{c}\text { Sig } \\
\text { (2-tailed) }\end{array}$ \\
\hline 1 & Self-Awareness & Pre-post Experiment & 49.557 & 8 & 26.645 & 2.306 & 0.000 \\
\hline \multirow[t]{2}{*}{2} & Self-Acceptance & Pre-post Experiment & 52.300 & 8 & 45.892 & 2.306 & 0.000 \\
\hline & & Pre-post Control & -6.891 & & -2.262 & 2.306 & 0.054 \\
\hline 3 & Self-Assertiveness & Pre-post Experiment & 54.333 & 7 & 24.608 & 2.365 & 0.000 \\
\hline 4 & & Pre-post Control & -1.714 & & 0.407 & 2.447 & 0.698 \\
\hline \multirow[t]{2}{*}{5} & Self-Responsibility & Pre-post Experiment & 50.083 & 7 & 23.782 & 2.365 & 0.000 \\
\hline & & Pre-post Control & -3.043 & & -1.133 & 2.365 & 0.295 \\
\hline
\end{tabular}

IJERE Vol. 7, No. 3, September 2018: 236-243 


\begin{tabular}{|c|c|c|c|c|c|c|c|}
\hline No & $\begin{array}{c}\text { Dimensions and } \\
\text { Development }\end{array}$ & Group & Mean & $\mathrm{df}$ & $\mathrm{t}$ count & $\mathrm{t}$ table & $\begin{array}{c}\text { Sig } \\
\text { (2-tailed) } \\
\end{array}$ \\
\hline \multirow[t]{2}{*}{6} & Self-Integrity & Pre-post Experiment & 48.069 & 9 & 33.906 & 2.262 & 0.000 \\
\hline & & Pre-post Control & -6.968 & & -4.962 & 2.262 & 0.051 \\
\hline 7 & & Pre-post Control & -45.600 & & -8.546 & 2.144 & 0.051 \\
\hline
\end{tabular}

Table 2 revealed the value of $t_{\text {count }}>t_{\text {table }}$ or can be seen that the value of $\alpha=0.05>\operatorname{sig}(0.000)$, which means that $\mathrm{H}_{1}$ is accepted and $\mathrm{H}_{0}$ is rejected. This indicated that logo counseling model could improve low spiritual self-esteem problems in college students.

\subsection{Discussion}

Through the logo counseling intervention program and statistical test results, the improvement of low spiritual self-esteem problems were described and analyzed as follows.

\section{a. Self-Awareness}

Through the self-exploration technique, there was an increase in self-awareness from a pre-test average of $34.15 \%$ to become $83.70 \%$ in the post-test in Table 1 and similarly in Table 2 , as the value of $t_{\text {count }}$ ${ }_{(26.645)}>t_{\text {table (2.306) }}$ for statistical significance. For practical significance, the clients were able to empower themselves through an attitude change and moral support. Changes in attitude values was seen when the clients can share with each other, provide support, and give motivation, so the other clients can arise from bad conditions and look at the future enthusiastically. Self-exploration technique had been researched for increasing the self-awareness of clients with terminal cancer [32].

\section{b. Self-Acceptance}

Through the self-acceptance technique in the program, there was an increase in self-acceptance seen from average pre-test score of $32.07 \%$ to become $84.37 \%$ in the post-test as shown in Table 1 and similarly in Table 2 the value of $t_{\text {count (45.892) }}>t_{\text {table (2.306) }}$ for statistical significance. For practical significance, change of behavior was seen when there was a big mirror in front of the clients, they could reveal their feelings about their strengths and weaknesses. The clients even asked themselves again and again about their fear and then had the power to conquer it. The clients could accept something they dislike about themselves. The results are in line with research in military personnel suffering from PTSD regarding their self-acceptance [33] and in drug addicts [34].

\section{c. Self-Assertiveness}

Through the self-detachment technique, there was an increase in self-assertiveness from a pre-test average of $30.67 \%$ to become $85.00 \%$ in the post-test in Table 1 and as in Table 2 the value of $t_{\text {count (24.608) }}>$ $\mathrm{t}_{\text {table (2.365) }}$ for statistical significance. For practical significance, the clients were able to behave and act based on the standards, aspirations, goals, or values of other people. This was confirmed when they could improve themselves by thinking in a new perspective. Self-detachment had been used to increase self-assertiveness in african american children [35].

\section{d. Life Purpose}

Through self-transcendence technique in the program, there was an increase in purpose of life from a pre-test average of $32.38 \%$ to become $82.76 \%$ in the post-test in Table 1 and similarly found in Table 2

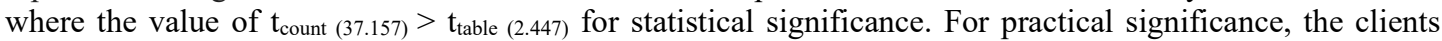
were able to develop a set of self-commitment values by doing various real activities to reach their life purpose. This was proven from awareness to do activities based on their interests, not just separate themselves from internal and external conditions, but have the ability to reach and find meaning outside of themselves. By involving themselves in activities that evoke spirit in love and a job, or facing a situation with the proper attitude, counseling can extend themselves in facing dysfunction and complicated behavior patterns, hyper-intention, and hyper-reflexion. These results are in line with research conducted in strengthbased counseling that self-transcendence able to help the client to discover his or her purpose of life [33].

\section{e. Self-Responsibility}

Through the behavior modification technique in the program, there was an increase in selfresponsibility from a pre-test average of $32.08 \%$ to become $82.17 \%$ in the post-test in Table 1 and the results in Table 2 with the value of $t_{\text {count (23.782) }}>t_{\text {table (2.365) }}$ for statistical significance. For practical significance, commitment of clients to have responsible husbands and for themselves to become responsible wives and mothers in taking care of children and husbands, was an attitude value. Changing an attitude value occurs 
when clients felt useful for other people and themselves by thinking positively, being honest, and having proper attitudes. Responsibility was related with self-control towards choices and actions in reaching a life purpose, having happiness, and values. These results are in line with research about passion activities and the sustainability of it supported by self-responsibility through behavior modification [36].

\section{f. Self-Integrity}

Through the self-integrity technique in the program, there was an increase in self-integrity from a pre-test average of $34.26 \%$ to become $82.33 \%$ in the post-test in Table 1 and also seen in Table 5 with the

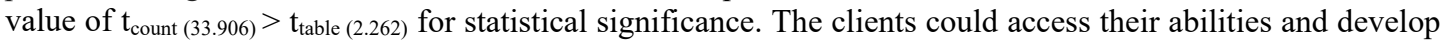
their self-confidence to discover meaning and their life purpose. The clients showed their cognitive abilities, using logic to reveal their attitude integrity. The clients realized they were distant from God, had bad relationships with others, and were grateful to return to the right path and be closer to God as well as have harmonious relationships with others, especially their families and close friends. These results are similar with findings of geriatric logotherapy for late-life depression [37].

\section{g. Meaning of Life}

Through a meaning orientation technique in the program, the meaning of life dimension increased from a pre-test average of 166.07 to become 452.27 in the post-test, as revealed in Table 1 and similarly in Table 5 the value of $t_{\text {count (43.851) }}>t_{\text {table (2.144) }}$ for statistical significance. For practical significance, the clients had learned how to respect life, respected their abilities as a blessing, and freed themselves from unfulfilled needs. There was positive self-esteem, in terms of self-potential, individual activities, and self-evaluation evaluated as showing positive improvements through a positive way of thinking towards themselves and other people. These results are in line with research conducted in cancer survivors that meaning of life can be a significant factor for physical and social functioning [38].

\section{CONCLUSION}

The low spiritual self-esteem problems happening among college students were caused by their inability to know their purpose and meaning of life. The purpose and meaning of life actually can be found in their daily life, but physical, social, and sexual pressure makes it difficult. Logo counseling was developed to help the clients to gain healthy self-esteem and also discover their purpose and meaning of life. Logo counseling consists of seven sessions to overcome the causal factors of low spiritual self-esteem problems and strengthen the six pillars of self-esteem.

The statistical significant level is high, from the recapitulation of average differential tests the value of the value of experimental group $t_{\text {count (43.851) }}>t_{\text {table (2.144). }} N$-gain of experimental group (0.75) $>N$-gain control group (0.15). This results indicated that the use of logo counseling program had given good result in the achievement of dynamic behavior changes.

This model is recommended for counselors, social workers, and other related agencies. However, before implementing this model, the relevant agencies should follow a special training program. Operational training guides have been developed based on the research results. Further research is recommended for researchers in the related field to better equip this model, especially how to overcome the barrier between counselors and college students via information technology [39].

\section{ACKNOWLEDGEMENTS}

This research was supported in part by grants from Direktorat Jenderal Pendidikan Perguruan Tinggi (DIKTI) of Republic Indonesia.

\section{REFERENCES}

[1] Akhter A. Relationship between Substance Use and Self-Esteem. Int J Sci Engineeering Res 013;4:1-7.

[2] Branden N. Power of Self-Esteem. Barnes \& Noble Books; 1992.

[3] Whelan A, Haywood P, Scott G. Low self-esteem: group cognitive behaviour therapy. Br J Learn Disabil 2007;35:125-30. doi:10.1111/j.1468-3156.2006.00418.x.

[4] Hayman JW, Kurpius SR, Befort C, Nicpon MF, Hull-Blanks E, Sollenberger S, et al. Spirituality Among College Freshmen: Relationships to Self-Esteem, Body Image, and Stress. Couns Values 2007;52:55-70. doi:10.1002/j.2161-007X.2007.tb00087.x.

[5] Engel JD. Nilai Dasar Logo Konseling. Yogyakarta: PT Kanisius; 2014.

[6] McManus F, Waite P, Shafran R. Cognitive-Behavior Therapy for Low Self-Esteem: A Case Example. Cogn Behav Pract 2009;16:266-75. doi:10.1016/j.cbpra.2008.12.007.

IJERE Vol. 7, No. 3, September 2018: 236-243 
[7] Sowislo JF, Orth U. Does Low Self-Esteem Predict Depression and Anxiety? A Meta-Analysis of Longitudinal Studies. Psychol Bull 2012;139:213-40. doi:10.1037/a0028931.

[8] Young S, Cashwell C, Shcherbakova J. The Moderating Relationship of Spirituality on Negative Life Events and Psychological Adjustment. Couns Values 2000;45:49. doi:10.1002/j.2161-007X.2000.tb00182.x.

[9] Hall PL, Tarrier N. The cognitive-behavioural treatment of low self-esteem in psychotic patients: A pilot study. Behav Res Ther 2003;41:317-32. doi:10.1016/S0005-7967(02)00013-X.

[10] Chatterton L, Hall PL, Tarrier N. Cognitive therapy for low self-esteem in the treatment of depression in an older adult. Behav Cogn Psychother 2007;35:365-9. doi:10.1017/S1352465807003608.

[11] Cajanding RJM. The Effectiveness of a Nurse-Led Cognitive-Behavioral Therapy on the Quality of Life, SelfEsteem and Mood Among Filipino Patients Living With Heart Failure: a Randomized Controlled Trial. Appl Nurs Res 2016;31:86-93. doi:10.1016/j.apnr.2016.01.002.

[12] Fennell MJ V. Low Self-Esteem: A Cognitive Perspective. Behav Cogn Psychother 1997;25:1-25. doi:10.1017/S1352465800015368.

[13] Slife BD, Williams RN. What's behind the research?: Discovering hidden assumptions in the behavioral sciences. Sage Publications; 1995.

[14] Waite P, McManus F, Shafran R. Cognitive behaviour therapy for low self-esteem: A preliminary randomized controlled trial in a primary care setting. J Behav Ther Exp Psychiatry 2012;43:1049-57. doi:10.1016/j.jbtep.2012.04.006.

[15] Johnsen TJ, Friborg O. The Effects of Cognitive Behavioral Therapy as an Anti-Depressive Treatment is Falling: A Meta-Analysis. Psychol Bull 2015;142:290. doi:10.1037/bul0000050.

[16] Kamya HA. Hardiness and spiritual well-being among social work students. J Soc Work Educ 2000;36:231-40. doi:10.1080/10437797.1998.10778937.

[17] Holloway M. Spirituality. Int Encycl Soc Behav Sci 2015;23:285-90. doi:10.1016/B978-0-08-097086-8.28093-8.

[18] Pedersen DM. Characteristics related to centrality of spiritual self-identity. Percept Mot Skills 1998;87:1359-68.

[19] Frankl VE. Man's Search for Meaning. Simon and Schuster; 1985. doi:10.1080/10503300903527393.

[20] Frankl VE. Man's Search for Ultimate Meaning 1976:190.

[21] Esping A. Autoethnography as Logotherapy: An Existential Analysis of Meaningful Social Science Inquiry Amber Esping Texas Christian University. J Bord Educ Res 2011;9:59-67.

[22] Smith AJ. Logotherapy to Treat Substance Abuse as a Result of Military- Related PTSD. J Mil Gov Couns 2013;1:61-74.

[23] Lim L, Saulsman L, Nathan P. Improving Self-Esteem 2005.

[24] Erol RY, Orth U. Self-esteem development from age 14 to 30 years: a longitudinal study. J Pers Soc Psychol 2011;101:607-19. doi:10.1037/a0024299.

[25] Hasnain N, Faraz B, Adlakha P. Self-Esteem And Happiness Of Children And Mothers Of Different Parental Authority. Int J Humanit Soc Stud 2013;1:1-6.

[26] Branden N. Nathaniel Branden's Self-Esteem Every Day: Reflections on Self-Esteem and Spirituality. Simon and Schuster; 1998.

[27] Ramiro MT, Teva I, Bermúdez MP, Buela-Casal G. Social support, self-esteem and depression: Relationship with risk for sexually transmitted infections/HIV transmission. Int $J$ Clin Heal Psychol 2013;13:181-8. doi:10.1016/S1697-2600(13)70022-X.

[28] Frankl VE. On the theory and therapy of mental disorders: An introduction to logotherapy and existential analysis. New York: Brunner-Routledge; 2004. doi:10.4324/9780203005897.

[29] Nazir M. Research Methods. Bogor: Ghalia Indonesia; 2009.

[30] Heppner PP, Wampold BE, Dennis M. Kivlighan J. Research Design in Counseling. Cengage Learning; 2007.

[31] Sugiyono. Quantitative Research Methods. Bandung: Alfabeta; 2012.

[32] Kang K-A, Im J-I, Kim H-S, Kim S-J, Song M-K, Sim S. The Effect of Logotherapy on the Suffering, Finding Meaning, and Spiritual Well-being of Adolescents with Terminal Cancer. J Korean Acad Child Heal Nurs 2009;15:136. doi:10.4094/jkachn.2009.15.2.136.

[33] Smith EJ. The Strength-Based Counseling Model. Couns Psychol 2006;34:13-79. doi:10.1177/0011000005277018.

[34] Rosdiana, Murti B, Wijaya M, Suwarto. The support to improve self-efficacy and healing of drug addict. Int $J$ Public Heal Sci 2016;5:359-66.

[35] Greene I. How to Improve Self-Esteem in The African American Child. San Diego: Baily Ave; 2003.

[36] Lafrenière MAK, Bélanger JJ, Sedikides C, Vallerand RJ. Self-esteem and passion for activities. Pers Individ Dif 2011;51:541-4. doi:10.1016/j.paid.2011.04.017.

[37] Morgan JH. Late-Life Depression and the Counseling Agenda: Exploring Geriatric Logotherapy as a Treatment Modality. Int J Psychol Res 2011;6:94-101.

[38] Jim HS, Andersen BL. Meaning in life mediates the relationship between social and physical functioning and distress in cancer survivors. Br J Health Psychol 2007;12:363-81. doi:10.1348/135910706X128278.

[39] Obi MC, Oye ND, Mohd TN, Bernice A. The Impact of ICT on Career Counseling Services : A case Study of Nigerian Secondary Schools. Int J Eval Res Educ 2012;1:1-15. 